\title{
PENGARUH SANKSI PERPAJAKAN TERHADAP KEPATUHAN WAJIB PAJAK ORANG PRIBADI
}

\author{
Denny Erica \\ Fakultas Teknik \& Informatika Universitas Bina Sarana Informatika \\ denny.dea@bsi.ac.id
}

\begin{abstract}
ABSTRAK
Pajak merupakan sumber pendapatan negara yang terbesar di Indonesia dan hal ini dapat terlihat di Anggaran Penerimaan dan Belanja Negara (APBN). Selain itu pajak juga menjadi salah satu sumber pendapatan APBN, yang dapat dipergunakan oleh negara untuk pembiayaan pembangunan nasional. Untuk meningkatkan sumber pendapatan negara dari sektor pajak, pemerintah mengeluarkan beberapa peraturan dan undang-undang yang terkait dengan sanksi pajak dengan harapan dapat mempengaruhi tingkat kepatuhan wajib pajak. Pada penelitian ini dilihat apakah ada pengaruh sanksi perpajakan terhadap kepatuhan wajib pajak orang pribadi di Indonesia, dan hasil perhitungan Uji Hipotesis yaitu: Uji t dan Uji F dengan menggunakan SPSS Versi 23, dimana t hitung $(16,009)>t$ tabel $(1,677)$ dan $\mathrm{F}$ hitung $(256,297)>\mathrm{F}$ tabel $(4,04)$, ada pengaruh yang signifikan dari sanksi pajak terhadap kepatuhan wajib pajak orang pribadi.
\end{abstract}

Kata Kunci: Sanksi, Kepatuhan, Wajib Pajak

\section{ABSTRACT}

Taxes are the largest source of state revenue in Indonesia and this can be seen in the State Revenue and Expenditure Budget (APBN). In addition, taxes are also a source of APBN revenue, which can be used by the state to finance national development. To increase the source of state revenue from the tax sector, the government issued several regulations and laws related to tax sanctions in the hope that it can affect the level of taxpayer compliance. In this study, it is seen whether there is an effect of tax sanctions on individual taxpayer compliance in Indonesia, and the results of the calculation of the Hypothesis Test are: T test and $F$ test using SPSS Version 23, where $t$ count (16.0o9)> $t$ table (1.677) and F count (256.297)> F table (4.04), there is a significant effect of tax sanctions on individual taxpayer compliance.

Keywords: Sanctions, Compliance, Taxpayers

Diterima: 30 Maret 2021; Direvisi: 6 April 2021; Diterbitkan: 20 April 2021

\section{PENDAHULUAN}

Pajak menjadi sumber pendapatan negara yang paling terbesar di Indonesia dan hal ini dapat terlihat di Anggaran Penerimaan dan Belanja Negara (APBN). Pajak merupakan salah satu sumber pendapatan dari APBN, yang dapat dipergunakan oleh negara untuk pembiayaan pembangunan nasional. (Erica, 2017)

Berdasarkan Undang-Undang Ketentuan Umum Perpajakan Nomor 16 Tahun 2009, Pasal 1, ayat 1, "Pajak adalah kontribusi wajib kepada negara yang terutang oleh orang pribadi atau badan 
yang bersifat memaksa berdasarkan Undang-Undang, dengan tidak mendapatkan imbalan secara langsung dan digunakan untuk keperluan negara bagi sebesarbesarnya kemakmuran rakyat.” (Republik Indonesia, 2013)

Menurut Rochmat Soemitro, "Pajak merupakan iuran kas negara yang didasarkan pada undang-undang (dapat dipaksakan) dengan tiada mendapat jasa timbal (kontra prestasi) yang langsung dapat ditunjukkan dan yang digunakan untuk membayar atas pengeluaran umum." (Mardiasmo, 2019)

Perpajakan di Indonesia menganut sistem Self Assessment, dimana pemerintah memberikan kepercayaan kepada wajib pajak untuk menghitung, menyetor, dan melaporkan sendiri atas kewajiban perpajakannya. Maka sebagai kesadaran dari kepatuhan wajib pajak dalam memenuhi kewajiban pajaknya yang sesuai dengan ketentuan yang berlaku, merupakan salah satu penentu pada keberhasilan sistem perpajakan di Indonesia. Meskipun pemerintah memberikan kepercayaan kepada wajib pajak dalam memenuhi kewajiban pajaknya dengan sistem Self Assessment, tetap ada pengawasan dari pemerintah untuk memastikan pemenuhan kewajiban pajaknya atas wajib pajak tersebut telah sesuai dengan peraturan perundangundang dan ketetapan perpajakan yang berlaku di Indonesia.

Untuk meningkatkan sumber pendapatan negara dari sektor pajak, pemerintah mengeluarkan beberapa peraturan dan undang-undang yang terkait dengan sanksi pajak dengan harapan dapat mempengaruhi tingkat kepatuhan wajib pajak. Masih tingginya tingkat ketidakpatuhan wajib pajak yang paling utama disebabkan oleh penghasilan wajib pajak atas pemenuhan kebutuhan hidupnya, hingga menimbulkan konflik antara kepentingan pribadi dengan kewajiban kepada negara. (Mahardika, 2015)

Tinggi rendahnya wajib pajak dalam mematuhi kewajiban perpajakannya dipengaruhi oleh beberapa faktor, salah satunya adalah kesadaran wajib pajak. (Siamena et al., 2017)

Tingkat kepatuhan dari wajib pajak dapat saja dipengaruhi oleh beberapa faktor, diantaranya yaitu pengenaan sanksi perpajakan, kualitas pelayanan, dan penerapan sistem administrasi perpajakan modern. (Savitri \& Nuraina, 2017)

\section{LANDASAN TEORI}

\section{Sanksi Pajak}

Pajak merupakan bentuk kontribusi wajib pajak kepada negara yang berlandaskan undang-undang, sehingga dapat dipaksakan dalam pelaksanaannya. Maka bagi wajib pajak yang tidak taat pajak serta tidak memenuhi kewajibannya untuk membayar pajak akan dikenakan sanksi pajak sebagai bentuk konsekuensi atas pelanggaran wajib pajak terhadap peraturan dan perundang-undangan pajak.

Sanksi perpajakan merupakan jaminan bahwa ketentuan perundangundangan perpajakan (norma perpajakan) akan dituruti, ditaati dan dipatuhi. Atau dengan kata lain sanksi 
perpajakan merupakan alat pencegah agar wajib pajak tidak melanggar norma perpajakan. (Mardiasmo, 2016)

Berdasarkan Undang-Undang Ketentuan Umum Perpajakan Nomor 16 Tahun 2009, sanksi pajak terbagi atas 2 (dua) yaitu: (a) sanksi administrasi, adalah pembayaran kerugian yang ditimbulkan wajib pajak kepada negara, dan pembayaran kerugian tersebut dapat berupa denda, bunga, dan kenaikan bayar, dan (b) sanksi pidana, adalah sanksi yang terdiri dari denda pidana, kurungan atau penjara atas tindak pelanggaran pajak. (Republik Indonesia, 2009)

Sanksi Pajak menciptakan keteraturan dan ketertiban perpajakan di Indonesia, serta sebagai dasar hukum bagi pemerintah untuk menentukan wajib pajak yang melanggar hukum. Berikut adalah indikator dari Variabel Sanksi Pajak (X) (Pujiwidodo, 2016), yaitu: (a) Wajib Pajak merasa bahwa sudah sepantasnya keterlambatan membayar pajak tidak diampuni dan harus dikenakan bunga, (b) Denda sebesar 2\% per bulan adalah wajar, (c) Pelaksanaan sanksi denda terhadap Wajib Pajak yang lalai oleh petugas pajak tepat pada waktunya, (d) Perhitungan pelaksanaan sanksi denda bunga terhadap Wajib Pajak yang lalai membayar pajak dilakukan oleh Wajib Pajak yang bersangkutan, (e) Sanksi pajak harus dikenakan kepada pelanggarnya tanpa toleransi, (f) Sanksi pidana yang dikenakan bagi pelanggar aturan pajak cukup berat, (g) Sanksi administrasi yang dikenakan bagi pelanggar aturan pajak sangat ringan, (h) Pengenaan sanksi yang cukup berat merupakan salah satu sarana untuk mendidik wajib pajak, (i) Pengenaan sanksi atas pelanggar pajak dapat dinegosiasikan, (j) Untuk Surat Pemberitahuan tahunan pajak penghasilan wajib pajak orang pribadi, paling lama 3 bulan setelah akhir tahun pajak.

\section{Kepatuhan Wajib Pajak}

Kepatuhan Wajib Pajak (WP) merupakan tindakan kepatuhan dan kesadaran atas pembayaran dan pelaporan dari kewajiban perpajakan masa dan tahunan oleh wajib pajak yang sesuai dengan peraturan perundangundangan dan ketentuan perpajakan.

Berdasarkan Peraturan Menteri Keuangan Nomor: 74/PMK.03/2012, bahwa kriteria kepatuhan wajib pajak, yaitu: (a) Tepat waktu pada saat menyampaikan Surat Pemberitahuan (SPT), (b) Tidak memiliki tunggakan pajak pada semua jenis pajak, terkecuali telah mendapatkan izin untuk mengangsur ataupun menunda atas pembayaran pajaknya, (c) Laporan keuangan di audit oleh pihak Akuntan Publik atau lembaga pengawasan keuangan pemerintah dengan pendapat Wajar Tanpa Pengecualian selama 3 (tiga) tahun berturut-turut, dan (d) Tidak pernah dipidana atas tindak pidana pada bidang perpajakan yang didasarkan pada putusan pengadilan yang telah mempunyai kekuatan hukum tetap dalam jangka 5 (lima) tahun terakhir. (Menteri Keuangan Republik Indonesia, 2012)

Secara umum ada 4 (empat) indikator atas kepatuhan pajak, yaitu: (a) Kepatuhan Wajib Pajak (WP) dalam mendaftarkan diri, (b) Kepatuhan Wajib 
Pajak (WP) untuk dapat menyetorkan kembali Surat Pemberitahuan (SPT) secara tepat waktu, (c) Kepatuhan atas penghitungan dan pembayaran pajak yang terutang dari penghasilan yang diperoleh oleh Wajib Pajak (WP), dan (d) Kepatuhan dari Wajib Pajak (WP) atas pembayaran dari tunggakan pajaknya baik itu pada Surat Tagihan Pajak (STP) ataupun Surat Ketetapan Pajak (SKP).

Faktor-faktor penyebab yang dapat menimbulkan tingkat rendahnya dari kepatuhan wajib pajak, diantaranya adalah rasa ketidakpuasan masyarakat terhadap pelayanan publik, pembangunan infrastruktur tidak merata, dan masih tingginya kasus korupsi pejabat tinggi. Pada bagian tanya jawab dari beberapa kegiatan atas sosialisasi terhadap perpajakan yang dilakukan, salah satu faktor penyebabnya adalah masyarakat yang kurang dapat merasakan manfaat dari pajak yang telah dibayarkan, misalnya masih tingginya fasiltas jalan umum yang rusak dan sarana publik umum yang masih dan tidak memadai serta tingginya tingkat kasus korupsi yang kerap dialami oleh pejabat eksekutif baik itu dari pemerintahan pusat ataupun daerah. (Saeroji, 2021)

Berikut adalah indikator dari Variabel dari Kepatuhan Wajib Pajak (WP) Orang Pribadi (Y) (Pujiwidodo, 2016), yaitu terdiri dari: (a) Secara umum dapat dikatakan bahwa Wajib Pajak (WP) paham dan berusaha memahami UndangUndang Perpajakan, (b) Wajib Pajak selalu mengisi formulir pajak dengan benar, (c) Wajib Pajak selalu menghitung pajak dengan jumlah yang benar, (d) Wajib Pajak selalu membayar tepat pada waktunya, (e) Wajib pajak selalu melapor tepat pada waktunya, (f) Tepat waktu dalam menyampaikan Surat Pemberitahuan (SPT) untuk semua jenis pajak dalam dua tahun terakhir, (g) Tidak mempunyai tunggakan pajak untuk semua jenis pajak, kecuali telah memperoleh izin untuk mengangsur atau menunda pembayaran pajak, (h) Tidak pernah dijatuhi hukuman karena melakukan tindak pidana dibidang perpajakan dalam jangka waktu 10 (sepuluh) tahun terakhir, (i) Penyampaian Surat Pemberitahuan (SPT) Masa yang terlambat dalam tahun terakhir untuk Masa pajak dari januari sampai november tidak lebih dari Masa pajak untuk setiap jenis pajak dan tidak berturut-turut, (j) Wajib pajak (WP) tidak pernah mendapat surat teguran. (Soehardi \& Untari, 2020)

\section{Kerangka Pemikiran}

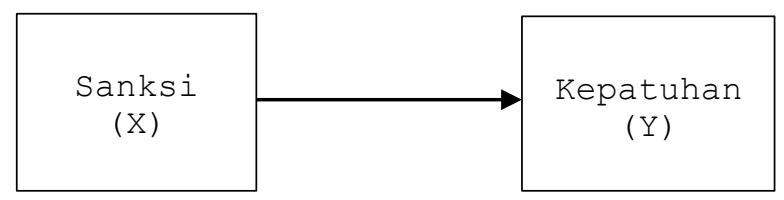

Gambar 1. Kerangka Pemikiran

\section{Hipotesis}

Ha :Terdapat pengaruh yang signifikan dari Sanksi Pajak atas Kepatuhan Wajib Pajak (WP) Orang Pribadi

Ho :Tidak terdapat pengaruh yang signifikan dari Sanksi Pajak terhadap Kepatuhan Wajib Pajak (WP) Orang Pribadi.

\section{METODE PENELITIAN}

\section{Jenis dan Pendekatan Penelitian}

Pada penelitian ini menggunakan penelitian penjelasan (explanation 
research) dengan pendekatan kuantitatif, dan penelitian ini merupakan jenis penelitian yang menjelaskan hubungan kausal antara variabel bebas dengan variabel terikat. Explanation Research merupakan jenis penelitian dimana peneliti menjelaskan hubungan antar variabel melalui pengujian hipotesis berdasarkan teori yang telah dirumuskan, kemudian data yang diperoleh dihitung melalui pendekatan kuantitatif. (Sugiyono, 2017)

Penelitian Kausal meneliti hubungan sebab-akibat antara dua variabel atau lebih, dimana penelitian ini menjelaskan pengaruh perubahan variasi nilai dalam suatu variabel terhadap perubahan variasi nilai variabel lain. Pada penelitian kausal, variabel independen sebagai variabel sebab dan variabel dependen sebagai variabel akibat. (Silalahi, 2015)

\section{Populasi dan Sampel}

Populasi dalam penelitian ini adalah Wajib Pajak (WP) KPP Pratama Jakarta Kebayoran Lama, Jl. Ciledug Raya No. 65, Kel. Ulujami, Kec. Pesanggrahan Jakarta Selatan. Populasi adalah keseluruhan subyek penelitian (Arikonto, 2016). Teknik pengumpulan sampel yang digunakan dengan menggunakan metode purposive sampling, metode ini merupakan pemilihan subyek penelitian yang berdasarkan penilaian atas karakteristik sampel yang akan diperoleh data yang sesuai dengan penelitian. (Silalahi, 2015)

\section{Teknik Pengumpulan Data}

Teknik pengumpulan data yang digunakan dalam penelitian ini menggunakan: (a) Dokumentasi, yaitu mencari data mengenai variabel berupa: catatan, transkrip, buku, surat kabar, majalah, notulen rapat, agenda, dan sebagainya (Arikonto, 2016), (b) Studi Pustaka, merupakan teknik pengumpulan data dengan mengadakan studi penelaah terhadap buku-buku, literatur, catatan, dan laporan-laporan yang kemungkinan ada hubungan dan kaitannya dengan permasalahan yang sedang dipecahkan (Nazir, 2014), (c) Observasi, merupakan teknik pengumpulan data terkait dengan perilaku manusia, proses kerja, gejalagejala alam dan bila responden yang diamati tidak terlalu besar (Sugiyono, 2017), dan (d) Metode Kuesioner, merupakan teknik pengumpulan data yang dilakukan dengan memberi seperangkat pertanyaan dan pernyataan tertulis kepada responden untuk dijawabnya (Sugiyono, 2017). Kuesioner digunakan dalam penelitian ini dimaksudkan untuk mengetahui tanggapan wajib pajak tentang pengaruh sanksi pajak terhadap kepatuhan wajib pajak orang pribadi. Dimana skala yang digunakan dalam penelitian ini dalah skala likert, yaitu skala yang digunakan untuk mengukur sikap, pendapat, dan persepsi seorang atau sekelompok orang tentang fenomena sosial (Sugiyono, 2017). Skala likert dalam penelitian ini dengan rincian, sebagai berikut: Skor 5 (lima) = Sangat Setuju (SS), Skor 4 (empat) = Setuju (S), Skor 3 (tiga) = Ragu-Ragu (RG), Skor 2 (dua) = Tidak Setuju (TS), Skor $1($ satu $)=$ Sangat Tidak Setuju (STS).

\section{Teknik Analisis Data}


Teknik Analisis Data Data yang akan dianalisa dalam penelitian ini berkaitan dengan apakah adanya hubungan antara variabel bebas (independen) dengan variabel terikat (dependen). Adapun analisis data yang akan digunakan dalam penelitian ini adalah: (a) Uji Validitas, untuk dapat mengetahui tingkat validitas dari suatu data penelitian, (b) Uji Reliabilitas, untuk dapat mengetahui tingkat konsistensi dari suatu data penelitian, (c) Uji Normalitas, dilakukan untuk dapat mengetahui apakah data dapat berdistribusi normal ataukah tidak, dan (d) Uji Hipotesis, yang akan diuji dalam penelitian ini berkaitan dengan ada atau tidaknya dari hubungan yang signifikan diantara variabel bebas (independen) terhadap variabel terikat (dependen).

\section{HASIL PENELITIAN DAN PEMBAHASAN}

\section{Uji Validitas}

Uji Validitas digunakan untuk mengetahui tingkat validitas angket dalam mengumpulkan data. Uji validitas dilakukan dengan rumus korelasi bivariate person dengan alat bantu Program SPSS Versi 23. Item angket dalam uji validitas dikatakan valid jika nilai $\mathrm{r}$ hitung $>\mathrm{r}$ table pada nilai signifikasi $5 \%$, berikut ringkasan dari hasil uji validitas berdasarkan dari hasil angket dari 50 (lima puluh) responden dalam penelitian ini, yaitu:
Tabel 1. Hasil Uji Validitas Sanksi Perpajakan (Varaibel X)

\begin{tabular}{|c|c|c|c|}
\hline $\begin{array}{c}\text { No. } \\
\text { Item }\end{array}$ & r hitung & r tabel & Keterangan \\
\hline 1 & 0,874 & 0,279 & Valid \\
\hline 2 & 0,881 & 0,279 & Valid \\
\hline 3 & 0,841 & 0,279 & Valid \\
\hline 4 & 0,739 & 0,279 & Valid \\
\hline 5 & 0,739 & 0,279 & Valid \\
\hline 6 & 0,704 & 0,279 & Valid \\
\hline 7 & 0,912 & 0,279 & Valid \\
\hline 8 & 0,704 & 0,279 & Valid \\
\hline 9 & 0,805 & 0,279 & Valid \\
\hline 10 & 0,805 & 0,279 & Valid \\
\hline
\end{tabular}

Sumber: Data diolah olah peneliti dengan SPSS

Tabel 2. Hasil Uji Validitas Kepatuhan WP OP (Variabel Y)

\begin{tabular}{|c|c|c|c|}
\hline $\begin{array}{c}\text { No. } \\
\text { Item }\end{array}$ & $\mathbf{r}$ hitung & r tabel & Keterangan \\
\hline 1 & 0,846 & 0,279 & Valid \\
\hline 2 & 0,798 & 0,279 & Valid \\
\hline 3 & 0,636 & 0,279 & Valid \\
\hline 4 & 0,681 & 0,279 & Valid \\
\hline 5 & 0,736 & 0,279 & Valid \\
\hline 6 & 0,319 & 0,279 & Valid \\
\hline 7 & 0,795 & 0,279 & Valid \\
\hline 8 & 0,361 & 0,279 & Valid \\
\hline 9 & 0,805 & 0,279 & Valid \\
\hline 10 & 0,385 & 0,279 & Valid \\
\hline
\end{tabular}

Sumber: Data diolah olah peneliti dengan SPSS

Hasil perhitungan Uji Validitas diatas, menunjukkan bahwa semua variabel memiliki nilai $\mathrm{r}$ hitung $>\mathrm{r}$ table pada nilai signifikasi $5 \%$, sehingga dapat dikatakan semua item dalam angket penelitian ini valid, dan dapat digunakan sebagai instrument penelitian.

\section{Uji Reliabilitas}

Uji Reliabilitas dilakukan dengan menggunakan rumus alpha. Uji signifikasi dilakukan pada taraf $\alpha=0,05$. Instrumen dapat dikatakan reliabel jika nilai alpha lebih besar dari $r$ tabel, dalam penelitian ini derajat bebas pengujian $=\mathrm{n}-\mathrm{k}=50-$ $2=48$, maka untuk nilai $\mathrm{r}$ tabel adalah 0,279 . 
Tabel 3. Reliabilitas Variabel X Reliability Statistics

\begin{tabular}{|c|r|}
\hline $\begin{array}{c}\text { Cronbach's } \\
\text { Alpha }\end{array}$ & N of Items \\
\hline .933 & 10 \\
\hline
\end{tabular}

Item-Total Statistics

\begin{tabular}{|l|r|r|r|r|}
\hline & $\begin{array}{c}\text { Scale Mean if } \\
\text { Item Deleted }\end{array}$ & $\begin{array}{c}\text { Scale } \\
\text { Variance if } \\
\text { Item Deleted }\end{array}$ & $\begin{array}{c}\text { Corrected } \\
\text { Item-Total } \\
\text { Correlation }\end{array}$ & $\begin{array}{c}\text { Cronbach's } \\
\text { Alpha if Item } \\
\text { Deleted }\end{array}$ \\
\hline item_1 & 36.38 & 10.281 & .847 & .922 \\
item_2 & 36.44 & 9.721 & .846 & .920 \\
item_3 & 36.36 & 10.480 & .810 & .925 \\
item_4 & 36.56 & 10.088 & .668 & .929 \\
item_5 & 36.56 & 10.088 & .668 & .929 \\
item_6 & 35.46 & 10.417 & .636 & .931 \\
item_7 & 36.46 & 9.804 & .889 & .918 \\
item_8 & 35.46 & 10.417 & .636 & .931 \\
item_9 & 36.24 & 9.574 & .740 & .926 \\
item_10 & 36.24 & 9.574 & .740 & .926 \\
\hline
\end{tabular}

Sumber: Data diolah olah peneliti dengan SPSS

Tabel 4. Reliabilitas Variabel Y Reliability Statistics

\begin{tabular}{|r|r|}
\hline $\begin{array}{c}\text { Cronbach's } \\
\text { Alpha }\end{array}$ & N of Items \\
\hline .834 & 10 \\
\hline
\end{tabular}

\begin{tabular}{|l|r|r|r|r|}
\multicolumn{5}{|c|}{ Item-Total Statistics } \\
\hline & $\begin{array}{c}\text { Scale Mean if } \\
\text { Item Deleted }\end{array}$ & $\begin{array}{c}\text { Scale } \\
\text { Variance if } \\
\text { Item Deleted }\end{array}$ & $\begin{array}{c}\text { Corrected } \\
\text { Item-Total } \\
\text { Correlation }\end{array}$ & $\begin{array}{c}\text { Cronbach's } \\
\text { Alpha if Item } \\
\text { Deleted }\end{array}$ \\
\hline item_1 & 38.00 & 6.245 & .779 & .789 \\
item_2 & 38.22 & 6.828 & .736 & .799 \\
item_3 & 37.94 & 7.078 & .525 & .818 \\
item_4 & 37.22 & 7.114 & .593 & .813 \\
item_5 & 38.18 & 6.763 & .645 & .806 \\
item_6 & 37.84 & 8.056 & .200 & .844 \\
item_7 & 37.94 & 6.221 & .701 & .798 \\
item_8 & 37.34 & 7.780 & .194 & .853 \\
item_9 & 38.12 & 7.169 & .760 & .804 \\
item_10 & 37.20 & 7.796 & .243 & .844 \\
\hline
\end{tabular}

Sumber: Data diolah olah peneliti dengan SPSS

Tabel 5. Uji Reliabilitas X dan Y

\begin{tabular}{|c|c|c|c|}
\hline Varaibel & r hitung & r tabel & Keterangan \\
\hline $\mathrm{X}$ & 0,933 & 0,279 & Reliabel \\
\hline $\mathrm{Y}$ & 0,834 & 0,279 & Reliabel \\
\hline
\end{tabular}

Hasil Uji Realiabilitas diperoleh nilai koefisien reabilitas angket $\mathrm{X}$ sebesar dan angket $\mathrm{Y}$ sebesar . Berdasarkan nilai koefisien reabilitas tersebut dapat dikatakan bahwa semua item pada angket penelitian ini reliabel atau konsisten, dan dapat digunakan sebagai instrumen penelitian.

\section{Uji Normalitas}

Uji Normalitas Kolmogorov Smirnov merupakan bagian dari uji asumsi klasik, yang bertujuan untuk mengetahui apakah nilai residual berdistribusi normal atau tidak. Model regresi yang baik adalah yang memiliki residual yang berdistribusi normal, dimana jika nilai signifikansi > 0,05 maka nilai residual berdistribusi normal, dan sebaliknya jika nilai signifikansi $<0,05$ maka residual tidak berdistribusi normal.

Tabel 6. Normalitas Kolmogorov-Smirnov

One-Sample Kolmogorov-Smirnov Test

\begin{tabular}{|c|c|c|}
\hline & & $\begin{array}{l}\text { Unstandardiz } \\
\text { ed Residual }\end{array}$ \\
\hline $\mathrm{N}$ & & 50 \\
\hline \multirow[t]{2}{*}{ Normal Parameters ${ }^{a, b}$} & Mean & .0000000 \\
\hline & Std. Deviation & 1.16554784 \\
\hline \multirow[t]{3}{*}{ Most Extreme Differences } & Absolute & .122 \\
\hline & Positive & .118 \\
\hline & Negative & -.122 \\
\hline \multicolumn{2}{|l|}{ Test Statistic } & .122 \\
\hline \multicolumn{2}{|l|}{ Asymp. Sig. (2-tailed) } & $.062^{\mathrm{c}}$ \\
\hline \multicolumn{3}{|c|}{ a. Test distribution is Normal. } \\
\hline \multicolumn{3}{|l|}{ b. Calculated from data. } \\
\hline \multicolumn{3}{|c|}{ c. Lilliefors Significance Correction. } \\
\hline
\end{tabular}

Sumber: Data diolah olah peneliti dengan SPSS

Berdasarkan dari hasil olah data dari uji normalitas dapat diketahui nilai signifikansi 0,062 > 0,05, maka dapat disimpulkan bahwasannya nilai residual berdistribusi normal.

\section{Uji Hipotesis}

Hipotesis dalam penelitian ini, yaitu: Hipotesis Alternatif (Ha) : Terdapat pengaruh yang signifikan dari sanksi 
pajak atas kepatuhan Wajib Pajak (WP) Orang Pribadi, Hipotesis Nihil (Ho) : Tidak terdapat pengaruh yang signifikan dari sanksi pajak terhadap kepatuhan wajib pajak orang pribadi. Dalam pengujian hipotesis untuk model regresi, derajat bebas ditentukan dengan rumus $=$ $\mathrm{n}-\mathrm{k}$, dimana $\mathrm{n}=$ banyaknya responden dan $\mathrm{k}$ = banyaknya variabel, dalam penelitian ini derajat bebas pengujian $=$ $50-2=48$, maka untuk nilai $t$ tabel adalah 1,677

\section{Uji t}

Dasar pengambilan keputusan: Jika sig $<0,05$ atau $\mathrm{t}$ hitung $>\mathrm{t}$ tabel $=$ maka terdapat pengaruh, sedangkan jika sig $>0,05$ atau $\mathrm{t}$ hitung $<\mathrm{t}$ tabel $=$ maka tidak terdapat pengaruh.

Tabel 7. Coefficients

\begin{tabular}{|c|c|c|c|c|c|c|}
\hline \multirow[b]{2}{*}{ Mode } & & \multicolumn{2}{|c|}{ Unstandardized Coefficients } & $\begin{array}{l}\text { Standardized } \\
\text { Coefficients }\end{array}$ & \multirow[b]{2}{*}{$t$} & \multirow[b]{2}{*}{ Sig. } \\
\hline & & $B$ & Std. Error & Beta & & \\
\hline \multirow[t]{2}{*}{1} & (Constant) & 11.109 & 1.937 & & 5.736 & .000 \\
\hline & Sanksi Pajak (X) & .768 & .048 & .918 & 16.009 & .000 \\
\hline
\end{tabular}

a. Dependent Variable: Kepatuhan WPOP (M)

Sumber: Data diolah olah peneliti dengan SPSS

Dari data diatas tersebut $t$ hitung $(16,009)>t$ tabel $(1,677)$, terdapat pengaruh yang signifikan dari sanksi pajak terhadap kepatuhan wajib pajak orang pribadi. Maka Ha diterima sedangkan Ho ditolak.

\section{Uji F}

Dasar pengambilan keputusan: Jika sig < 0,05 atau $\mathrm{F}$ hitung $>\mathrm{tF}$ tabel = maka terdapat pengaruh, sedangkan jika sig > 0,05 atau $\mathrm{F}$ hitung $<\mathrm{F}$ tabel $=$ maka tidak terdapat pengaruh.
Tabel 8. Anova

\begin{tabular}{|c|c|c|c|c|c|c|}
\hline \multicolumn{7}{|c|}{ ANOVA ${ }^{a}$} \\
\hline \multicolumn{2}{|c|}{ Model } & $\begin{array}{l}\text { Sum of } \\
\text { Squares }\end{array}$ & df & Mean Square & $F$ & Sig. \\
\hline \multirow[t]{3}{*}{1} & Regression & 355.433 & 1 & 355.433 & 256.297 & $.000^{b}$ \\
\hline & Residual & 66.567 & 48 & 1.387 & & \\
\hline & Total & 422.000 & 49 & & & \\
\hline \multicolumn{7}{|c|}{ a. DependentVariable: Kepatuhan WPOP (M) } \\
\hline b. $\mathrm{Pr}$ & ors: (Const & anksi Pajak & & & & \\
\hline
\end{tabular}

Formula menentukan $\mathrm{F}$ tabel, yaitu: $\mathrm{DF} 1=\mathrm{K}-1$ dan $\mathrm{DF} 2=\mathrm{N}-\mathrm{K}$, dimana $\mathrm{K}$ adalah jumlah variabel dan $\mathrm{N}$ adalah jumlah responden. Pada penelitian ini $\mathrm{DF} 1=2-1=1$ dan $\mathrm{DF} 2=5 \mathrm{O}-1=49$, maka nilai $\mathrm{F}$ tabel $=4,04$. Pada data diatas F hitung $(256,297)>\mathrm{F}$ tabel $(4,04)$, terdapat pengaruh yang signifikan dari sanksi pajak terhadap kepatuhan wajib pajak orang pribadi. Maka Ha diterima sedangkan Ho ditolak.

\section{Pembahasan}

Dari hasil olah data dengan menggunakan SPPS versi 23 yang diwujudkan pada Tabel 7. Coefficient untuk Uji $t$, menunjukkan hasil bahwa $t$ hitung $(16,009)$ lebih besar dari pada $t$ tabel (1,677), maka terdapat pengaruh yang signifikan dari sanksi pajak terhadap kepatuhan wajib pajak orang pribadi. Sehingga $\mathrm{Ha}$ diterima sedangkan Ho ditolak.

Dari hasil olah data pada Tabel 8. Anova Uji F, menunjukkan F hitung $(256,297)$ lebih besar dari pada $F$ tabel $(4,04)$, maka terdapat pengaruh yang signifikan dari sanksi pajak terhadap kepatuhan wajib pajak orang pribadi. Sehingga $\mathrm{Ha}$ diterima sedangkan Ho ditolak. 
Dari hasil olah data Uji t dan Uji F tersebut membuktikan bahwa Kepatuhan Wajib Pajak (WP) Orang Pribadi telah dipengaruhi secara signifikan oleh Sanksi Pajak yang sesuai dengan peraturan dan ketentuan perpajakan yang berlaku di Indonesia.

\section{KESIMPULAN}

Perpajakan menjadi sumber pendapatan negara yang paling terbesar di Indonesia, sehingga pemerintah memberikan sanksi pajak bagi wajib pajak yang melakukan pelanggaran pajak, untuk mengurangi dan mengatasi permasalahan rendahnya tingkat kepatuhan pajak di Indonesia. Dan hasilnya pada penelitian ini ada pengaruh yang signifikan dari sanksi pajak terhadap kepatuhan wajib pajak orang pribadi

\section{Saran}

Untuk dapat lebih memperluas dan memperdalam seberapa jauh tingkat kepatuhan wajib pajak orang pribadi dapat ditambahkan pada penelitian selanjutnya dengan variabel lainnya seperti variabel penghasilan dan pengetahuan wajib pajak orang pribadi.

\section{Daftar Pustaka}

Arikonto, S. (2016). Prosedur Penelitian Suatu Pendekatan Praktik. Rineka Cipta.

Erica, D. (2017). Prosedur Penghitungan Terhadap Pengampunan Pajak Di Indonesia. Ecodomica, 1 No. 1 (April 2017), 10-17.

Mahardika, I. G. N. P. (2015). PENGARUH KUALITAS PELAYANAN DAN SIKAP WAJIB PAJAK TERHADAP KEPATUHAN PELAPORAN WAJIB PAJAK ORANG
PRIBADI DI KPP PRATAMA

SINGARAJA. Jurnal Jurusan

Pendidikan Ekonomi (JJPE), 5(1), 1-

12.

Mardiasmo. (2016). Perpajakan (Edisi

Revi). Andi.

Mardiasmo. (2019). PERPAJAKAN. CV Andi.

Menteri Keuangan Republik Indonesia. (2012). Peraturan Menteri Keuangan Republik Indonesia Nomor 74/PMK.O3/2O12.

Nazir, M. (2014). Metode Penelitian. Ghalia Indonesia.

Pujiwidodo, D. (2016). Persepsi Sanksi Perpajakan Terhadap Kepatuhan Wajib Pajak Orang Pribadi. Jurnal Online Insan Akuntan, 1(No. 1), 92116.

Republik Indonesia. (2009). Peraturan Pemerintah Republik Indonesia Nomor 16 Tahun 2009 Tentang Pajak Penghasilan Atas Penghasilan Berupa Bunga Obligasi. Republik Indonesia.

Republik Indonesia. (2013). UndangUndang Ketentuan Umum

Perpajakan dan Peraturan Pelaksanaannya. Kementrian Keuangan Republik Indonesia Direktorat Jenderal Pajak.

Saeroji, O. (2021). Menakar Kadar Kepatuhan Wajib Pajak. Direktorat Jenderal Pajak.

Savitri, F., \& Nuraina, E. (2017). Pengaruh

Sanksi Perpajakan Terhadap

Kepatuhan Wajib Pajak Orang

Pribadi Di Kantor Pelayanan Pajak

Pratama Madiun. Jurnal

Equilibrium, 5(No. 1), 45-55.

Siamena, E., Sabijono, H., \& Warongan, J. D. . (2017). PENGARUH SANKSI PERPAJAKAN DAN KESADARAN WAJIB PAJAK TERHADAP KEPATUHAN WAJIB PAJAK ORANG PRIBADI DI MANADO. Jurnal Riset Akuntansi Going 
Concern, 12(2), 917-927.

Silalahi, U. (2015). Metode Penelitian Sosial Kuantitatif. PT Refika

Aditama.

Soehardi, S., \& Untari, D. T. (2020). The Effect of Covid-19 Pandemic on Hotel Employees, Hotel Occopancy Rates and Hotel Tax Income in Jakarta,
Indonesia. Systematic Reviews in Pharmacy, 11(12), 964-972. https://doi.org/10.31838/srp.2020.5. 138

Sugiyono. (2017). Metode Penelitian Kuantitatif, Kualitatif, dan R\&D. CV Alfabeta. 